\title{
In Memoriam: Mary Anne Lee MD FRCP(C)
} 1945-2001

My friend and colleague, Dr. Mary Anne Lee died on May 16, 2001. We are very saddened by her passing.

Mary Anne Lee was born in Montreal, and raised and educated in Toronto. She obtained an Honours BSc at the University of Toronto, then entered and graduated from medical school at the University of Toronto in 1971. Her internship was completed at the Toronto Western Hospital, and Internal Medicine as well as Neurology residencies were completed at the University of Toronto. Mary Anne's FRCPC in Internal Medicine was completed in 1975 and in Neurology, in 1977. She spent time as a research fellow in the EEG laboratory at the University of Western Ontario with Warren Blume, and at the University of Uppsala in Sweden with Erik Stålberg. She served as a lecturer at the University of Toronto until 1981 before moving to Calgary. Mary Anne was a staff Neurologist at Foothills Hospital, director of Clinical Neurophysiology at Foothills Hospital from 1981-2000 and served as president of the Foothills medical staff in 1995. She taught medical students, internal medicine residents, neurology residents and neurophysiology fellows at the University of Calgary. Her expertise was in epilepsy, EEG and EMG and she served as president of the Canadian Society of Clinical Neurophysiologists from 1994 to 1996 and was director of the University of Calgary epilepsy clinic. Mary Anne was a regular participant and contributor to the Canadian Congress of Neurological Sciences each year and she served as a the Book Editor for the Canadian Journal of Neurological Sciences from 1992 to 1996.

Mary Anne was a very special person in our department. She

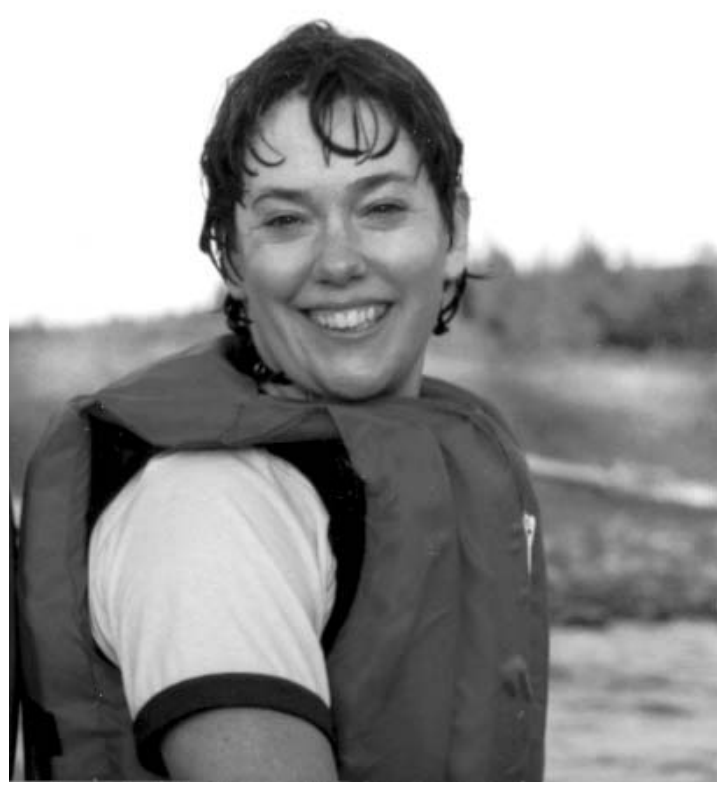

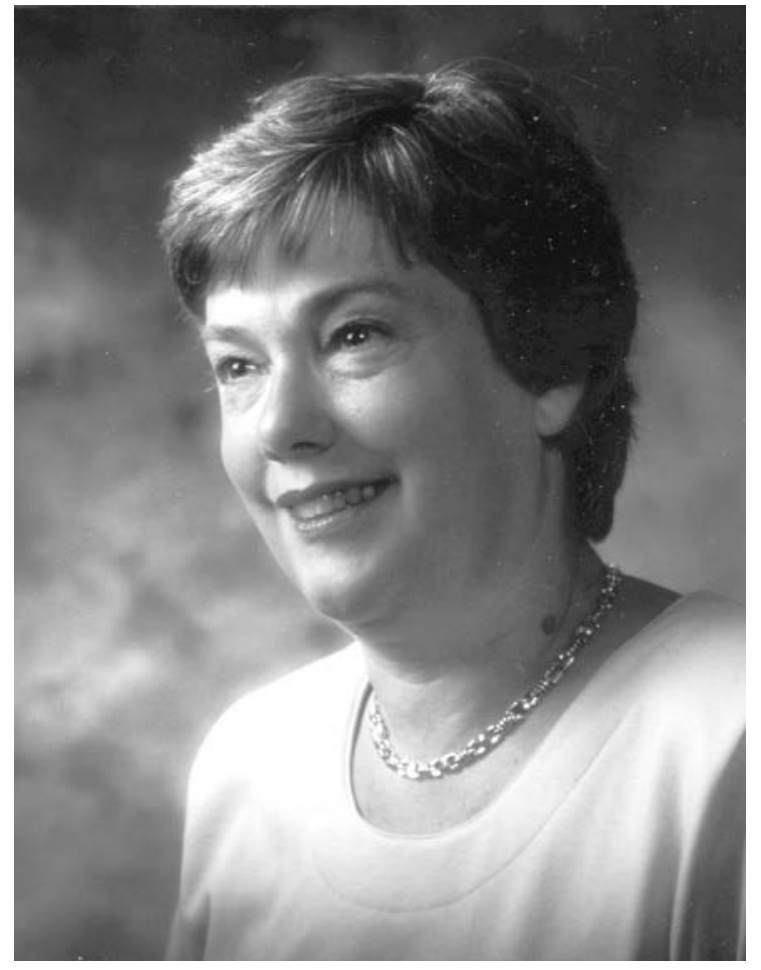

was a dedicated and tireless contributor to the clinical workload whether in the labs or on the duty roster. A great deal of her time was spent managing a large and grateful community of patients with epilepsy, some of whom underwent cortical resections, others who were managed on conventional or study drugs. She created a paperless EEG lab, and a video-EEG monitoring unit second to none. Her colleagues, technologists and staff in the Neurophysiology labs were like a close and very dedicated family to her. While not an epileptogist, I learned many things about epilepsy from Mary Anne. A few spring to mind. One was an instance of vigabatrin psychosis she identified, when such reports were very infrequent and none of the rest of us knew about it. Another was her practical take on how to deal with the issue of driving in patients with single seizures. Some were a little more lighthearted. About two months ago, Mary Anne was anxious to show me the video-EEG monitor of a very unique patient. This young man with complex partial seizures was a very serious, religious person who was always formal, except during his seizures. During every seizure (the origin of which she was able to localize precisely), the patient would swear "fuddleduddle" (expletive changed) fairly emphatically. Mary Anne was confident that she had identified the "fuddle-duddle" center in the brain. 
Mary Anne had a similar level of high quality expertise in EMG including single fiber studies and macro studies. Mary Anne and I had concurrent EMG clinics on Thursday afternoons. Highlights included who would be doing what inpatients added to the regular list that day, what suspicious problems from the WCB we both had to see, and what kind of licorice Mary Anne had in a drawer under the EEG reading board that week. She would joke about dictation errors, like the time from a colleague when "intraoperative room corticography" came out as "intraoperative room pornography" or when "peroneal nerve stimulation" was instead "perineal nerve stimulation". At one stage, when we worked in adjacent labs, we would crank up the audio volume during needle electromyography to get a second opinion from one another or we would invite each other in to meet a patient. I believe she was generally more helpful to me than I to her.
Outside of work, Mary Anne had an abiding love for animals, particularly her beloved golden retriever, and for the mountains at her cabin in Kananaskis. She climbed mountains in the Rockies, trekked in Nepal and Africa, downhill skied, and enjoyed white wine especially after a long and arduous hike. She had a wide circle of colleagues and friends, many of whom packed a large lecture theatre recently, standing room only, to honour this very special and gifted person. She leaves behind two brothers, Dr. Robert Lee and Barry Lee, as well as many nieces and nephews. Mary Anne, we are better for having known you, but your loss to us is profound.

\section{Douglas Zochodne} Calgary, Alberta

[Donations can be made to a lectureship in Mary Anne Lee's name through the Department of Clinical Neurosciences, 1195 Foothills Hospital, 1403 - 29th Street NW, Calgary AB T2N 2T9] 